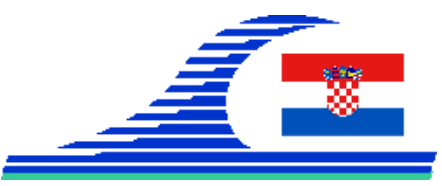

Conférence Méditerranéenne Côtière et Maritime

EDITION 4, SPLIT, CROATIA (2017)

Coastal and Maritime Mediterranean Conference

Disponible en ligne - http://www.paralia.fr - Available online

\title{
Observations of shoreline changes on a pocket gravel beach: Baška beach, Croatia
}

\author{
Igor RUŽIĆ ${ }^{1}$, Suzana ILIĆ ${ }^{2}$, Čedomir BENAC ${ }^{1}$, Nino KRVAVICA ${ }^{1}$
}

1. University of Rijeka, Faculty of Civil Engineering, R. Matejčić 3, 51000 Rijeka, Croatia.

2. Lancaster University, Lancaster Environment Centre, Farrer Avenue, Lancaster, LA1 4YQ, UK.

iruzic@.uniri.hr

\begin{abstract}
:
The Baška beach, one of the largest gravel beaches in Croatia was monitored over 3 years. This paper presents analysis of the shoreline position derived from these measurements. The shoreline position and the beach width were calculated from beach profile measurements. Overall changes in shoreline positions were quite small except in areas affected by fresh-water input (stream and urban runoff) and near a groyne. Several storm events were covered during the observation period. In most of these cases, the shoreline retreat was registered as expected. This would be followed by a rapid beach recovery and resulting shoreline advancement. After NE (Bura) storm wind event the shoreline advancement was registered. However, the close inspection of the beach profiles showed that this registered shoreline advancement was due to accumulation of sediment at the toe of the beach. This material was eroded at the upper beach. This finding and the lack of beach rotation indicate that the cross-shore sediment processes dominate during the energetic events.
\end{abstract}

\section{Keywords:}

Gravel beach, Adriatic Sea, Beach monitoring, Shoreline, Beach width.

\section{Introduction}

Most beaches on the Croatian coast are small pocket gravel beaches formed by the deposition of sediment from torrential flows. These torrential flows are main contributors to sediment supply in particular during rainy periods, as observed in other beach systems on high-relief coasts (INMAN \& JENKINS, 1999). However, man-made structures built for the regulation of torrential flows, and afforestation in coastal catchments due to the abandonment of agriculture, interrupted natural sediment supply in the last few decades. Additionally, the sediment which is mainly derived from karstified carbonate rocks (PIKELJ \& JURAČIĆ, 2013) is prone to wave abrasion. This also contributes to the reduction in the beach volumes. Nearshore processes are 
Mediterranean rocky coasts:

Features, processes, evolution and problems

responsible for re-distribution of sediment on the beaches and also for the permanent loss of sediment offshore on very steep bathymetries found in the Eastern Adriatic Sea. Rapid coastal urbanisation and various coastal structures built on the shoreline have also restricted the natural dynamic of beaches.

Beaches on the Croatian coast are important for tourism and hence for the economy of the country. Many beaches have been renourished, enlarged or constructed in areas where they did not exist earlier. Many of these have been constructed without prior knowledge of the natural coastal dynamics and sediment budgets and hence they usually require interventions. The aim of the study presented here was to set-up the regular monitoring of the Baška beach, Kvarner Bay, North Adriatic, which would enhance understanding of this beach system and inform future beach nourishment projects. The shoreline position and the beach width were calculated from surveys taken in the last three years.

\section{Field site and field measurements}

The Baška beach is located in the south-eastern part of the island Krk in Kvarner Bay (NW of the Croatian coast) in a cove called Bašćanska Draga. It is a $1.5 \mathrm{~km}$ long, NESW, embayed natural beach. Scree cliffs on the south-western side are exposed to wave erosion and contribute to the sediment supply. Cliffs are minor source of beach sediments, opposite to the neighbourhood Stara Baška where cliff erosion plays significant role to the beach sediment supply (RUŽIĆ et al., 2014; 2015). However, most of the supply comes from the $26 \mathrm{~km}^{2}$ catchment of the long stream Vela Bašćanska Ričina. This torrential watercourse is $12 \mathrm{~km}$ long and it is the longest watercourse found on Adriatic islands. The sediment brought by the stream, from the catchments, is derived from flysh and carboniferous rocks such as limestone. The mean diameter size of beach gravel is $18 \mathrm{~mm}$, while finer sediment classified as sand is deposited nearshore. Due to land use changes and regulation of the torrential channel, there has been a significant reduction in sediment supply. This reduction and exposure to waves driven by winds Bura (NE) and Sirocco (SE), as well as sediment abrasion have resulted in decrease of the beach width. Due to wave refraction in the embayment, waves usually arrive shore-normal to the beach. Both cross-shore and longshore sediment processes are present on this beach. Longshore sediment transport is generally weak and sediment is transported from the beach edges towards the centre; from SW to NE during Sirocco and from NE to SW during Bura. Tidal range is very small and tidal processes have a minor role in shaping beach face. The strongest winds and hence waves, and the most rainfall and hence the largest discharges occur in winter months. However, there is also a possibility of high-intensity rainfall events during mostly dry summer months.

Figure 1 shows the location of the beach and location and timings of beach surveys. The beach is separated into three different morphological areas (figure 1): Palada (north- 
eastern side), Vela Plaža (central part) and Zarok (south-western side). The beach is surrounded by houses, seawall and other accompanied infrastructure, which interrupt its natural retreat. The beach was nourished from the beginning of 1980, since 2003. Several groynes were built in 1990's to retain the sediment on the beach (CAPIĆ, 2005).

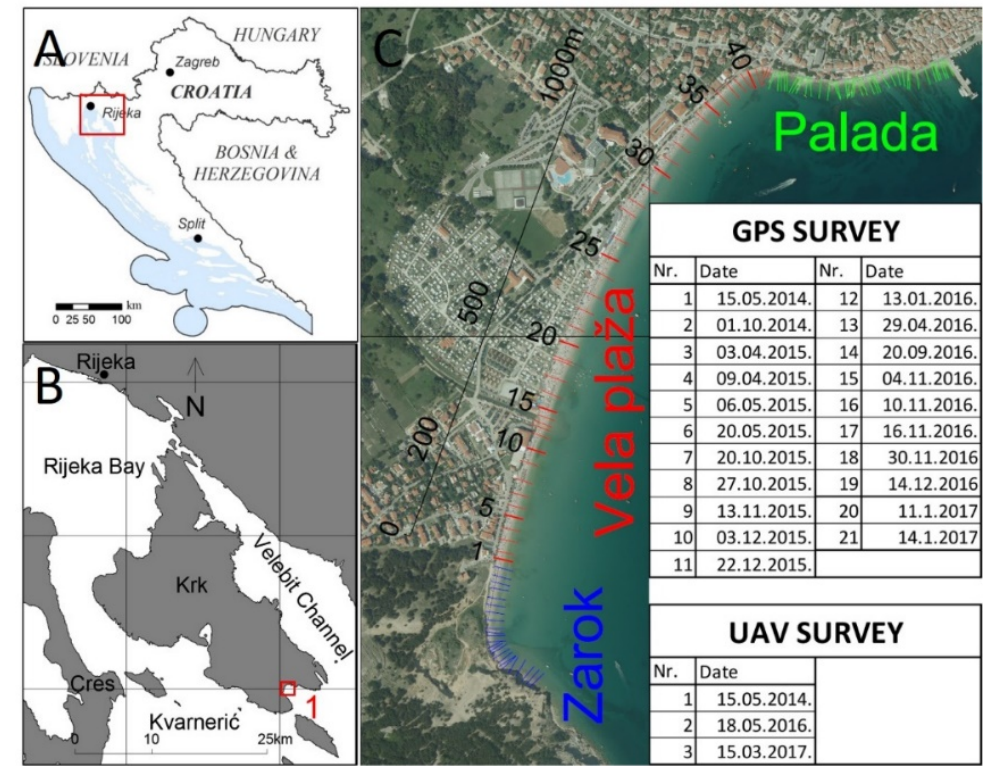

Figure 1. Location of Baška beach: a) in Croatia; b) in Kvarner Bay; c) location of measured beach profiles and timings of surveys.

The beach monitoring started in May 2014 after the renewed beach nourishment. The surveys were conducted throughout the year aiming to record changes caused by more energetic events. Figure 1 shows the location of beach profiles (1-44). Beach profiles are spaced approximately every $30 \mathrm{~m}$. The measurements are taken over the sub aerial part of the beach down to $0.20 \mathrm{~m}$ depth, using the RTK-GPS. In addition, surveys were taken using Unmanned Automatic Vehicle in 2014, 2016 and 2017. In this paper, we will focus on results from RTK-GPS surveys on the central part Vela Plaža, covering beach profiles 1-44.

\section{Results and discussion}

The shoreline location at elevation of $0.25 \mathrm{~m}$ above sea level was derived from profile measurements. On the basis of these, parameters such the mean beach width, the minimum and the maximum beach width and the variance were calculated for each profile. Figure 2 shows the derived beach parameters along the beach. It can be seen that the beach width varies along the shoreline, which is influenced by extension of buildings and other built infrastructure. The smallest beach width is found between 
Mediterranean rocky coasts:

Features, processes, evolution and problems

profiles 40 and 45. This part of the beach was nourished in April 2014 but the sediment was lost from the system by October that same year.

Figure 2 also shows that the recorded changes are quite small but there are several distinctive areas were these changes are more pronounced.

The largest changes were observed between profiles 11 and 15. This is not surprising as these profiles are located near the mouth of the stream. The width and the location of the mouth change in accordance with changes in the stream discharge throughout the year. During the dry period, the mouth closes up and the beach width increases. During the wet period, the mouth enlarges and sediment is transported to the nearshore zone where is deposited in a lobe. This results in the beach width reduction. The channel also moves from east to west and vice versa depending on the wave direction. The second largest changes were registered in profile 27 . The area around this profile is influenced by the overspill of urban runoff and scouring processes at edges of the sea wall during high water levels in storm conditions.

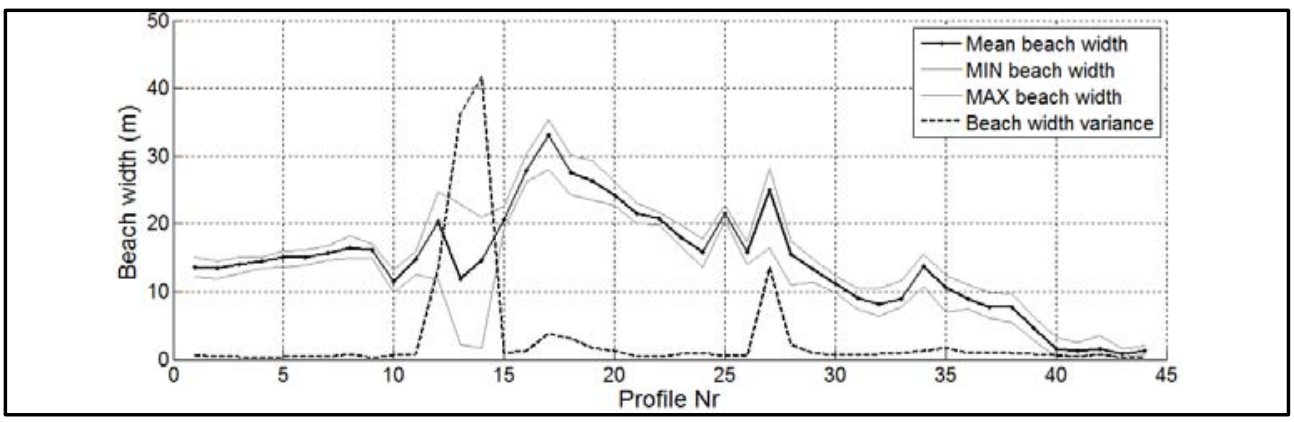

Figure 2. Beach width parameters (15.5.2014-14.1.2017).

A sudden drop in beach elevation was recorded in September 2016, after a highintensity rainfall when this part of the beach was completely washed away. Other noticeable changes were recorded between profiles 16-19. These profiles are affected by erosion and deposition on each side of a groyne and the stream mouth.

The largest reduction in the beach width was registered between $10^{\text {th }}$ and $16^{\text {th }}$ November 2016, as seen in profile 34 in figure 3. This was due to waves driven by Sirocco (SE) wind followed by Bura (NE) wind. During subsequent Bura event (28 ${ }^{\text {th }}$ November), the beach with increased. However, this increase was due to a developed storm profile rather than an increase in beach volume. Figure 3 clearly illustrate the loss of material on the upper beach and accumulation of sediment at the toe of the beach, forming a step, between $16^{\text {th }}$ and $30^{\text {th }}$ November.

Overall, these surveys revealed that longshore sediment transport is present in much localised areas e.g. between river mouth and a groyne. Also, a beach rotation observed on some other pocket beaches in the Kvarner Bay has not been registered. Changes in beach elevations indicate that cross-shore rather than longshore processes have a 
Mediterranean rocky coasts:

Features, processes, evolution and problems

dominant role in shaping the beach. This is also in agreement with nearshore wave directions, being mostly shore-normal due to wave refraction in the embayment. Moreover, it seems that the beach can recover quickly after an erosional event. The hypothesis derived here on the basis of this short-term monitoring will be evaluated by further beach measurements accompanied by hydrodynamic measurements and numerical modelling. It will be also interesting to find our whether the newly renourished beach will behave in a similar way.

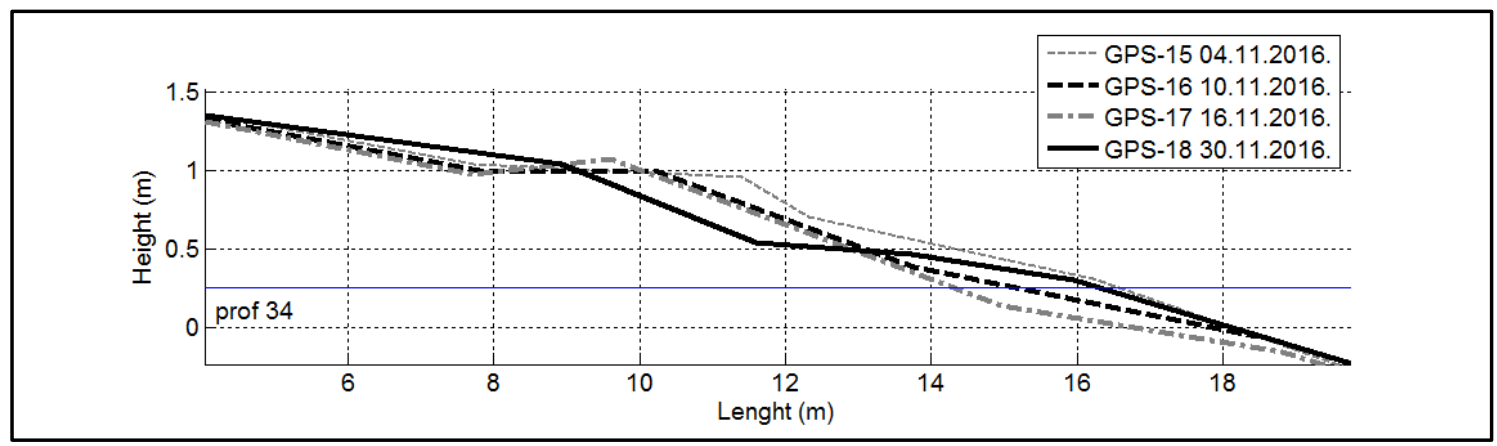

Figure 3. Beach profiles measured at profiles 5 and 34 in November 2016; blue line shows elevation of $0.25 \mathrm{~m}$.

\section{Conclusion}

Overall no significant changes in beach width were observed. The largest changes take place around the mouth of the torrential stream and in the area, which is influenced by the urban runoff. Groynes and other structures built in immediate hinterland of the beach have an effect on beach dynamics. Some of smaller changes observed are due to changes in cross-shore changes of beach profiles. These short-term measurements revealed that the beach is dominated by cross-shore sediment transport, in particular between storm events. Longshore sediment transport has secondary, usually localised role.

\section{References}

CAPIĆ M. (2005). Saniranje potpornoga zida šetnice i formiranje plaže u Baški na Krku. Časopis građevinar 57, pp. 163-167.

INMAN D. L., JENKINS S. A. (1999). Climate change and the episodicity of sediment flux of small California rivers. J. Geol., 107, pp. 251-270. doi: 10.1086/314346

PIKELJ K., JURAČIĆ M. (2013). Eastern Adriatic Coast (EAC): Geomorphology and coastal vulnerability of a karstic coast. Journal Coastal Research, Vol. 29, pp. 944-957. doi: 10.1029/2004GL019723

RUZIC I., BENAC Č., MAROVIC I., ILIC S. (2015). A stability assessment of coastal cliffs using digital imagery. Acta Geotech. Slov., 25, pp. 25-35. 
Mediterranean rocky coasts:

Features, processes, evolution and problems

RUZIC I., MAROVIC I., BENAC Č., ILIC S. (2014) Coastal cliff geometry derived from structure-from-motion photogrammetry at Stara Baška, Krk Island, Croatia. GeoMarine Letters, 34 (6), pp. 555-565. doi: 10.1007/s00367-014-0380-4 